\title{
REVIEW
}

\section{Tales of the Tail and Sperm Head Aches Changing concepts on the prognostic significance of sperm pathologies affecting the head, neck and tail}

\author{
Héctor E Chemes ${ }^{1}$ and Cristian Alvarez Sedo ${ }^{1,2}$
}

This article presents an update on the variable prognostic significance of different sperm pathologies in patients with severe male factor infertility due to morphology and motility disorders. Severe asthenozoospermia is one of the leading causes of male infertility as spermatozoa cannot reach the oocyte and/or penetrate normally. Identifying structural causes of sperm immotility was of great concern before the advent of intracytoplasmic sperm injection (ICSI), because immotility was the limiting factor in the treatment of these patients. In these cases, in vitro methods are used to identify live spermatozoa or stimulate sperm motility to avoid selection of non-viable cells. With these advances, fertilization and pregnancy results have improved dramatically. The identification of genetic phenotypes in asthenozoospermia is important to adequately inform patients of treatment outcomes and risks. The one sperm characteristic that seriously affects fertility prognosis is teratozoospermia, primarily sperm head and neck anomalies. Defects of chromatin condensation and acrosomal hypoplasia are the two most common abnormalities in severe teratozoospermia. The introduction of microscopic methods to select spermatozoa and the development of new ones to evaluate sperm quality before ICSI will assure that ultrastructural identification of sperm pathologies will not only be of academic interest, but will also be an essential tool to inform treatment choice. Herein, we review the differential roles played by sperm components in normal fertilization and early embryo development and explore how assisted reproductive technologies have modified our concepts on the prognostic significance of sperm pathologies affecting the head, neck, mid-piece and tail.

Asian Journal of Andrology (2012) 14, 14-23; doi:10.1038/aja.2011.168; published online 26 December 2011

Keywords: acrosomal hypoplasia; chromatin anomalies; fertility prognosis; intracytoplasmic sperm injection; intracytoplasmic injection of morphologically selected spermatozoa; sperm neck defects; sperm pathologies; tail abnormalities; teratozoospermia

\section{INTRODUCTION}

Knowledge of the spermatozoon dates back to the seventeenth century when Anton van Leeuwenhoek first described them in human semen: 'What I investigate is only what, without sinfully defiling myself, remains as a residue after conjugal coitus...'. He described a multitude of 'animalculi seminis (little animals in semen) less than a millionth the size of a coarse grain of sand and with thin, undulating transparent tails' (Leeuwenhoek to William Brouncker, November 1677). His observations were reported in a letter to the Royal Society of London, to which he eventually was to become a fellow. In another letter dated 12 June 1716, he wrote this very clever account of what enthusiastic observations and the writing of papers mean for scientists up to this day: 'my work, which I have done for a long time, was not pursued in order to gain the praise I now enjoy, but chiefly from a craving after knowledge, which I notice resides in me more than in most other men. And therewithal, whenever I found anything remarkable, I found it my duty to put down my discovery in paper, so that all ingenious people may be informed thereof'. Leeuwenhoek went on to document his discovery with very detailed drawings that depict with unusual detail the main characteristics of spermatozoa and a striking morphologic heterogeneity that, beyond the accuracy of his observations, is the first rendition of what we now call teratozoospermia (Figure 1).

The very concept of teratozoospermia is something that needs to be revisited because it is based on the identification of atypical sperm shapes but does not recognize the cellular basis of their functional incompetence. ${ }^{1,2}$ Sperm pathology is the discipline of characterizing structural and functional deficiencies in abnormal spermatozoa. ${ }^{3}$ The question could be asked: 'what is wrong with wrong sperm shape? What hides behind a head-shape change in amorphous or tapering spermatozoa? In other words, what is it that impairs sperm function in morphologically abnormal sperm? Is it just abnormal shape or is there something wrong with specific sperm components?' ... 'Ultrastructural evaluation of teratozoospermia coupled with immunocytochemistry and molecular techniques have allowed a precise characterization of sperm abnormalities including their structural molecular and functional aspects. This approach goes beyond descriptive morphology of the appearance of spermatozoa'. ${ }^{3}$ The main idea is to shed new light into the physiopathology of sperm abnormalities based in the study of ${ }^{1}$ Laboratory of Testicular Physiology and Pathology, Center for Research in Endocrinology, National Research Council (CONICET), Endocrinology Division, Buenos Aires Children's
Hospital, Gallo 1330, C1425SEFD Buenos Aires, Argentina and ${ }^{2}$ Centro de Estudios en Ginecología y Reproducción (CEGyR), C1425SEFD Buenos Aires, Argentina Correspondence: Professor HE Chemes (hchemes@cedie.org.ar)

Received: 5 November 2011; Revised: 10 November 2011; Accepted: 14 November 2011; Published online: 26 December 2011 

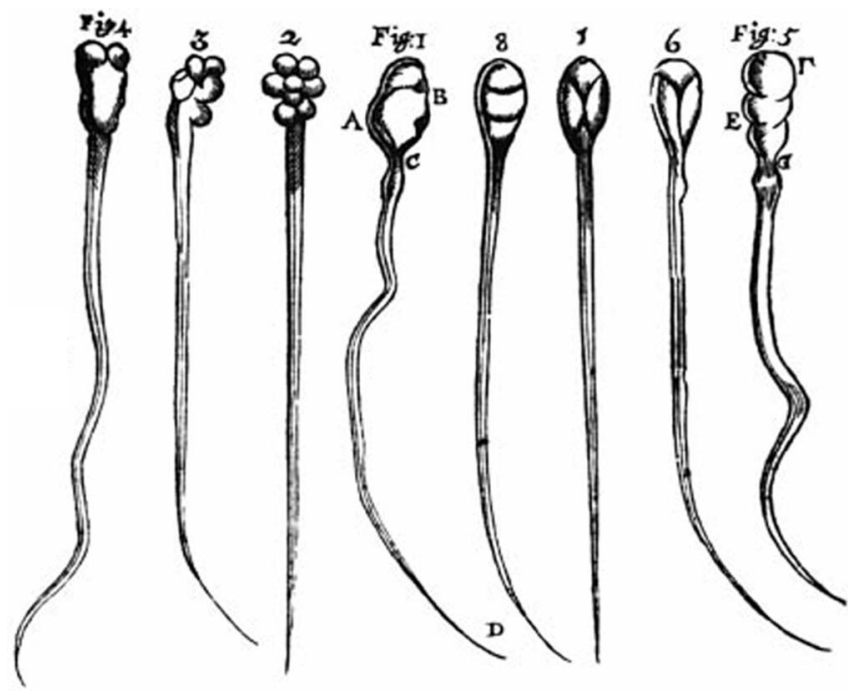

Figure 1 First drawing of mammalian spermatozoa by A. van Leeuwenhoek (around 1677) that inspired this description by C. Huygens (1678). '... They are formed of a transparent substance, their movements are very brisk and their shape is similar to that of frogs before their limbs are formed.' Note the clear identification of heads, mid-pieces and tails and the remarkable morphologic heterogeneity of sperm heads.

the striking structural and chemical modifications that spermatid organelles and chromatin suffer during spermiogenesis.

The advent of intracytoplasmic sperm injection (ICSI) has revolutionized the field of assisted reproductive technologies and removed formerly challenging barriers for the treatment of patients with severe male factor infertility. Before the introduction of ICSI, sperm immotility and tail abnormalities seriously compromised the sperm ability to reach and fertilize the oocyte. As we will see, sperm microinjection techniques have demonstrated that, once the spermatozoon is within the oocyte cytoplasm, the tail does not play a significant role in fertilization. The one sperm characteristic that remains seriously affecting fertility prognosis is teratozoospermia, primarily sperm head and neck anomalies. In the present article, we will review the differential roles played by different sperm components in normal fertilization and early embryo development and explore how current assisted reproductive technologies have modified our concepts on the prognostic significance of sperm pathologies affecting the head, neck, mid-piece and tail.

\section{NUCLEAR CHANGES DURING SPERMIOGENESIS}

The head of mature spermatozoa is the result of spermiogenesis, a complex differentiation process, during which the larger, round and predominantly euchromatic nuclei of early spermatids evolve to the smaller, oval-spatulate, heterochromatic head of mature sperm. Decrease in nuclear size is due to chemical and architectural modifications of DNA-protein complexes that lead to chromatin condensation, while the reshaping of the head is the result of cytoplasmic forces exerted by microtubules of the manchette and development of the acrosome.

The organization of DNA and nuclear proteins undergo remarkable modifications during spermiogenesis. In early round spermatids, DNA is mainly associated with nuclear histones, globular proteins that form an octamer (the 'core' particle) encircled by a 146-base pair DNA filament resulting in a structure resembling 'beads in a string'. The process of chromatin condensation is the consequence of spatial macromolecular modifications derived from the replacement of histones first by transition proteins and ultimately by nuclear protamines. This produces a radically different nucleoprotein structure with protamines lodged in minor DNA grooves, which allows for a tight parallel association of protamine and DNA molecules and further DNA stabilization by crosslinking of disulphide bonds ${ }^{4,5}$ (Figure 2). This is the molecular basis of chromatin condensation, a process that is clearly observed during spermiogenesis as the transition from a fine granularity of the chromatin in early steps to increasing degrees of aggregation into coarser and closer granules that eventually reach the homogeneous quality of chromatin seen in mature sperm that 'effectively renders chromatin invulnerable to most external influences $^{4}$ (Figure 2). During this process, there are smaller areas of the nucleus $(0.1-0.2 \mu \mathrm{m})$ that remain uncondensed and manifesting a fine granulofilamentous substructure. While this process is taking place, pores move caudally and concentrate in the redundant nuclear envelope that demarcates the clear nuclear pocket around the sperm neck. Polyubiquitinated proteins have been found in the nucleus of rat spermatids and human spermatozoa, and proteasomes are present in the small uncondensed chromatin regions and nuclear pocket area. ${ }^{6}$ In normal cells, proteasomes are proteolytic macromolecular complexes that digest Polyubiquitinated proteins. Their fluctuations during spermiogenesis are synchronized with the turnover of DNA associated proteins and therefore play an important role in chromatin condensation and remodeling by degrading nuclear histones and transitional proteins that are being replaced by newly arrived nuclear protamines. According to these authors, 'the nuclear pocket might be the degradation site for temporarily functioning proteins generated during condensation of chromatin in late spermatids'. Other components, such as the SPAN-X protein have also been localized in nuclear 'vacuoles' and the redundant nuclear envelope of human spermatozoa. ${ }^{7}$ These observations indicate that proteolysis of disposable proteins by the ubiquitin-proteasome system is actively operational in non-condensed areas of the chromatin and caudal pocket area allowing the exit of proteolytic residues from the nucleus through the caudal pore rich area of the redundant nuclear envelope.

\section{SPERM HEAD ANOMALIES}

Only a few sperm pathologies are associated with characteristic changes in morphology of spermatozoa. The lack of an acrosome

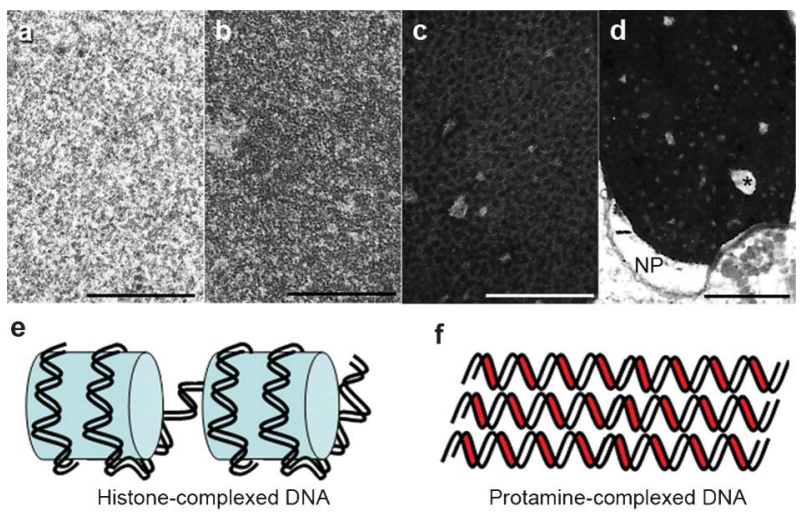

Figure 2 The upper four panels depict progressive stages in chromatin condensation during spermiogenesis (a: round spermatid, b: elongating spermatid, c: almost mature spermatid). Mature spermatozoa (d) have complete condensation, clear small uncondensed areas (asterisk) and the nuclear pocket (NP) near the neck region. Bars $=1 \mu \mathrm{m}$. The two bottom drawings illustrate the relationship of DNA strands to histones (light blue, e) or protamines (red, f). Note the closer packing of DNA-protamine complexes. 
usually determines the round shape of the sperm nucleus, insufficient centrosomal function results in acephalic spermatozoa or tail implantations not aligned with the sperm axis, and dysplastic development of the tail cytoskeleton leads to the short, thick and irregular flagella of dysplasia of the fibrous sheath. ${ }^{8,9}$ However, in most teratozoospermias, there is no direct relationship between defined sperm anomalies and characteristic sperm shapes. This is particularly so for 'amorphous', 'tapered' or 'pyriform' heads, whose presence does not identify the underlying anomaly. It is in these cases when a thorough diagnosis is necessary, because identifying the sperm defect may suggest strategies to improve reproductive outcome. Many chromatin and acrosomal anomalies fall within this category.

Alterations in chromatin condensation are the most frequent nuclear pathology in severe teratozoospermia. They are not associated with a particular sperm head shape and even though particularly frequent in 'amorphous' spermatozoa, they can also be seen with many other head configurations, including oval sperm heads. When observed with the electron microscope they appear as big (1$3 \mu \mathrm{m}$ ) electron lucent areas or 'lacunar' defects of irregular shapes, sharply delimited from normally compacted chromatin and not limited by a membrane. ${ }^{3,10-13}$ Their contents are finely granular or fibrillar with some denser granular areas probably corresponding to more condensed chromatin (Figure 3). Lacunae indicate serious defects in chromatin structure and function. It was earlier suggested that they may correspond to apoptotic changes, but no correlation with chromatin fragmentation has been reported in later studies. ${ }^{14-16}$ Deficiencies in the process of histone removal, diminution or absence of nuclear protamine $\mathrm{P} 2$ or alterations in the $\mathrm{P} 1-\mathrm{P} 2$ ratio have been reported in infertile men, but their possible relation with nuclear lacunae here described has not been documented (reviewed in Ref. 21). ${ }^{17-20}$ Diminution of the P1/P2 ratio has been reported in patients with diminished in vitro fertilization performance. ${ }^{22}$ Even

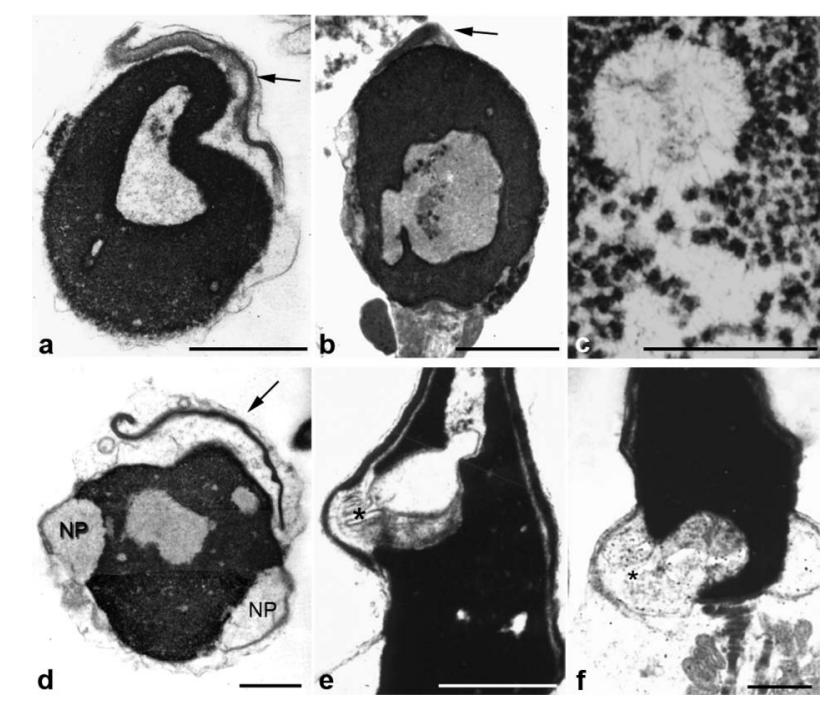

Figure 3 Chromatin and acrosomal anomalies. The six panels depict spermatozoa with abnormal morphology and serious defects of chromatin condensation (nuclear lacunae). Nuclei show big areas of rarefaction with uncondensed chromatin of granular and fibrillar substructure (c). Some denser spots probably represent more condensed chromatin. Nuclear pockets (NP) are prominent (d) and show continuity with uncondensed chromatin (asterisks, e and f). Panels $\mathbf{a}$ and $\mathbf{b}$ show small acrosomes (acrosomal hypoplasia, arrows). In panels $\mathbf{a}$ and $\mathbf{d}$ small acrosomes are detached from nuclei ( $\mathbf{a}$ and $\mathbf{d}$ ). Bars $=1 \mu \mathrm{m}$. $\mathbf{b}$ is reproduced with permission from Chemes. $^{12}$ though extensive studies have been conducted searching for protamine gene mutations as a cause of male infertility the results have so far been scarce. ${ }^{5}$ Diminished fertility potential has been described in mice with targeted disruption of Camk4 and transition protein 1 genes or in transgenic models expressing heterologous avian protamines. $^{23-25}$

As seen before, the ubiquitin proteasome system has an important role in the physiological removal of proteins during the histoneprotamine transition. Proteolysis probably takes place in small uncondensed chromatin areas and the nuclear pocket of normal spermatozoa. ${ }^{6}$ We propose that the larger lacunae of abnormal chromatin condensation here described are their pathological counterparts, probably resulting from increased proteolysis of histones and transition proteins by an overactive or disregulated ubiquitin proteasome system. The frequent connections between chromatin lacunae and unusually large nuclear pockets (Figure 3) tend to confirm this suggestion, since the nuclear pocket is a proteolytic center and the exit site from which protein residues leave the nucleus.

Infertile patients carrying lacunar defects of chromatin condensation have diminished fertilization rates, abnormal early embryonic development or increased pregnancy loss during the first trimester. ${ }^{11-13}$ Chromatin lacunae are probably equivalent to the nuclear 'vacuoles' described using high magnification by Bartoov et al. ${ }^{26-28}$ However, the term 'vacuoles' is probably incorrect, since most nuclear lacunae are not membrane-bound. Methods of sperm selection at high magnification to avoid the microinjection of 'vacuolated' spermatozoa have resulted in conflicting reports. Higher embryo quality, implantation and pregnancy rates have been reported by some groups, but these results were not confirmed in other communications (Table 1). Sperm chromatin deficiencies are one of the most important causes of fertility failure in humans and it is advisable to investigate them in all patients with high percentages of abnormal spermatozoa.

Lack and insufficient acrosomal development are two head anomalies compromising fertility. They originate from abnormalities of the acrosome, a Golgi-derived sperm organelle that covers the anterior two-thirds of the sperm nucleus and is involved in sperm penetration and oocyte activation. Spermatozoa without acrosomes frequently display spherical nuclei, hence the denomination of globozoospermia. The alterations that result in round acrosomeless nuclei are closely related to malfunction of the Sertoli cell F-actin hoops that embrace spermatid nuclei and of the acrosome-acroplaxome-manchette complex, all structures that model sperm head shape. ${ }^{29}$ An association between lack of acrosome and round heads is not always found because it is possible to find either acrosomeless spermatozoa with oval heads or round-headed sperm with small acrosomes (Figure 4). Globozoospermia was one of the first sperm pathologies to be recognized (reviewed in Ref. 3). ${ }^{30-35}$ Studies on testicular biopsies have demonstrated that they derive from an abnormal development of Golgi proacrosomic vesicles that fail to attach and or spread over the spermatid nucleus. As the result, unattached acrosomes are absent from mature spermatozoa because they are eliminated within residual bodies before sperm release (Alvarez Sedo et al., in preparation). We now believe this to be the most common mechanism to explain the origin of acrosomeless spermatozoa, and not acrosomal 'aplasia' or 'agenesis' (absent formation) as we and other authors had previously proposed. $3,10,11,36$ The reason for this lack of attachment probably lies in abnormalities of the perinuclear theca, a cytoskeletal protein complex of Golgi origin that directs acrosomal attachment and expansion over the nucleus. ${ }^{37,38}$ Perinuclear theca proteins are located under the acrosome in normal spermatozoa and are diminished and/or 
Table 1 Intracytoplasmic sperm injection (ICSI) outcome in patients with defective chromatin condensation (nuclear vacuoles)

\begin{tabular}{|c|c|c|c|c|c|c|c|}
\hline Author & Treatment & $\begin{array}{c}\text { Number of oocytes } \\
\text { per cycle }\end{array}$ & $\begin{array}{c}\text { Fertilization } \\
\text { rate }(\%)\end{array}$ & $\begin{array}{c}\text { Good } \\
\text { embryos (\%) }\end{array}$ & $\begin{array}{l}\text { Implantation } \\
\text { rate }(\%)\end{array}$ & $\begin{array}{c}\text { Pregnancy } \\
\text { rate (\%) }\end{array}$ & Miscarriage rate (\%) \\
\hline Bartoov et al.. ${ }^{28} 2003$ & $\begin{array}{l}\text { ICSI } \\
\text { IMSI }\end{array}$ & $\begin{array}{l}50 \\
50\end{array}$ & $\begin{array}{l}65.5 \\
64.5\end{array}$ & $\begin{array}{l}31 \\
45.2 *\end{array}$ & $\begin{array}{c}9.5 \\
27.9 *\end{array}$ & $\begin{array}{l}30 \\
60 *\end{array}$ & $\begin{array}{l}33 \\
9.0 *\end{array}$ \\
\hline Hazout et al., ${ }^{97} 2006$ & $\begin{array}{l}\text { ICSI } \\
\text { IMSI }\end{array}$ & $\begin{array}{l}125 \\
125\end{array}$ & $\begin{array}{l}65.2 \\
68.1\end{array}$ & $\begin{array}{l}32.6 \\
42.6\end{array}$ & $\begin{array}{c}0.8 \\
20.3^{*}\end{array}$ & $\begin{array}{c}2.4 \\
37.6 *\end{array}$ & $\begin{array}{c}100 \\
15 *\end{array}$ \\
\hline Berkovitz et al., ${ }^{98} 2006$ & $\begin{array}{l}\text { ICSI } \\
\text { IMSI }\end{array}$ & $\begin{array}{l}80 \\
80\end{array}$ & $\begin{array}{l}69.1 \\
67.4\end{array}$ & $\begin{array}{l}25.7 \\
38.7 *\end{array}$ & $\begin{array}{c}9.4 \\
31.3^{*}\end{array}$ & $\begin{array}{l}25 \\
60 *\end{array}$ & $\begin{array}{l}40 \\
14 *\end{array}$ \\
\hline Antinori et al., ${ }^{99} 2008$ & $\begin{array}{l}\text { ICSI } \\
\text { IMSI }\end{array}$ & $\begin{array}{l}219 \\
227\end{array}$ & $\begin{array}{l}94.5 \\
94.8\end{array}$ & - & $\begin{array}{l}11.3 \\
17.3^{*}\end{array}$ & $\begin{array}{l}26.5 \\
39.2^{*}\end{array}$ & $\begin{array}{l}24.1 \\
16.9\end{array}$ \\
\hline Wilding et al., ${ }^{100} 2011$ & $\begin{array}{l}\text { ICSI } \\
\text { IMSI }\end{array}$ & $\begin{array}{l}8 \\
8\end{array}$ & $\begin{array}{l}79.4 \\
70.1\end{array}$ & $\begin{array}{l}60.3 \\
83.6^{*}\end{array}$ & $\begin{array}{c}0 \\
20.8^{*}\end{array}$ & $\begin{array}{c}0 \\
37.5\end{array}$ & - \\
\hline Balaban et al.., 2011 & $\begin{array}{l}\text { ICSI } \\
\text { IMSI }\end{array}$ & $\begin{array}{l}84 \\
84\end{array}$ & $\begin{array}{l}80.9 \\
81.6\end{array}$ & $\begin{array}{l}- \\
-\end{array}$ & $\begin{array}{l}19.5 \\
28.9\end{array}$ & $\begin{array}{l}44.4 \\
54.0\end{array}$ & - \\
\hline Oliveira et al., ${ }^{102} 2011$ & $\begin{array}{l}\text { ICSI } \\
\text { IMSI }\end{array}$ & $\begin{array}{l}100 \\
100\end{array}$ & $\begin{array}{l}62 \\
65.4\end{array}$ & - & $\begin{array}{r}13.6 \\
9.8\end{array}$ & $\begin{array}{l}26 \\
19\end{array}$ & $\begin{array}{l}15.4 \\
31.6\end{array}$ \\
\hline
\end{tabular}

Abbreviation: IMSI, intracytoplasmic injection of morphologically selected spermatozoa.

Women age: 30-37 years.

Number of transferred embryos: $2-4$.

$* P<0.05$, compared with ICSI.

unattached to nuclei in acrosomeless spermatozoa (Alvarez Sedo et al., in preparation). ${ }^{39}$

Acrosomal hypoplasia is a frequent component of severe teratozoospermia, is readily recognizable with the electron microscope or after a careful light microscopic examination, and should be diagnosed because the consequences of insufficient acrosomal function are sometimes treatable by the use of methods to stimulate $\mathrm{Ca}^{++}$fluxes within the oocyte during ICSI (Table 2). We have reported on 35 patients with acrosome developmental anomalies. ${ }^{12}$ Seven of them corresponded to acrosomeless spermatozoa (four with the typical globozoospermic morphology and three with a mixture of round, oval or amorphous sperm heads). The other 28 patients evidenced different degrees of acrosomal hypoplasia and some acrosomeless forms. Small and detached acrosomes with diminished contents characterize acrosomal hypoplasia (Figure 4). In these cases, perinuclear theca proteins are also absent, diminished and detached from spermatid nuclei. Acrosomal hypoplasia and globozoospermia may coexist in

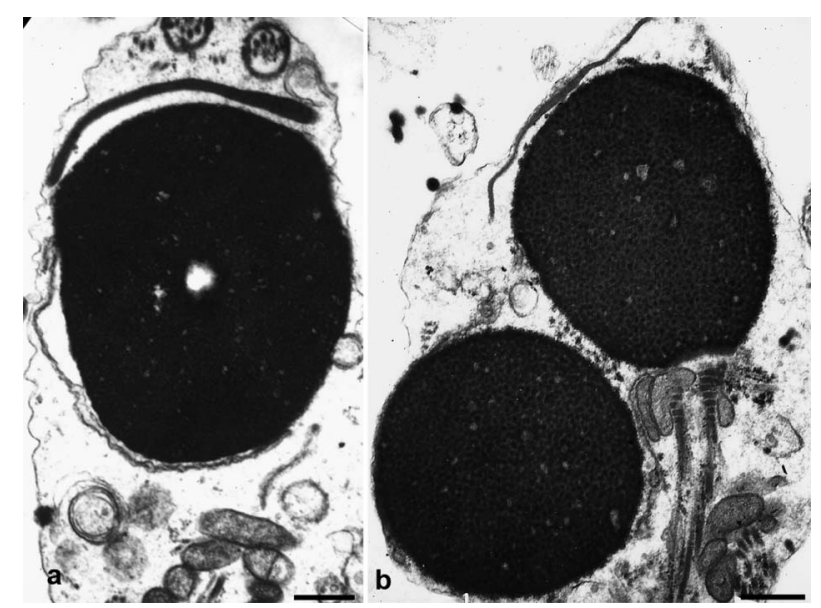

Figure 4 Spermatozoa with round or spheroidal heads. There is one acrosomeless round nucleus (panel b, bottom), and two spheroidal nuclei with acrosomal hypoplasia (panels $\mathbf{a}$ and $\mathbf{b}$, upper part). The chromatin is normally condensed. Bars $=1 \mu \mathrm{m}$. the same semen sample. While globozoospermia is easily identifiable in semen analysis, acrosomal hypoplasia is largely underdiagnosed and frequently remains unrecognized in severe teratozoospermia. This is the reason why it is not possible to estimate the prevalence of this condition among infertile males.

Absence and hypoplasia of the acrosome combine frequently with insufficient chromatin condensation or nuclear lacunae, which worsens their fertility potential. Family incidence has been reported in both entities. ${ }^{34,40}$ Two very recent publications have identified a frequent homozygous deletion in chromosome 12 in four out of five infertile brothers and 15 out of 20 other unrelated men, all with globozoospermia. $^{41,42}$

Patients suffering from acrosome anomalies are infertile because spermatozoa are unable to penetrate the oocyte. The introduction of ICSI was anticipated to offer a solution for these men, but this was not always the case. Subsequent research pointed to insufficient activity of perinuclear theca proteins which were found to be involved in triggering $\mathrm{Ca}^{++}$oscillations responsible for oocyte activation. ${ }^{43-45}$ In vitro activation by electric pulses, oocyte incubation with $\mathrm{Ca}^{++}$ionophore or with strontium has been tried with variable success (Table 2). ${ }^{46,47}$ These conflicting results suggest a more intricate regulation of oocyte activation and fertilization than previously anticipated and highlight the complexity of alterations in the basic mechanisms of sperm functioning.

\section{PATHOLOGIES OF THE SPERM NECK}

The neck of spermatozoa is the site of articulation between the head and tail, and comprises the sperm centriole and connecting piece. During spermiogenesis, the axoneme of the tail grows from the distal centriole while the proximal centriole migrates to the caudal pole of the nucleus and attaches to it. Around the centriolar pair assembles the complex structure of the connecting piece, a dense protein cylinder formed by nine longitudinal columns closed cranially by the capitulum that articulates with the sperm nucleus. ${ }^{48,49}$ At the final stages of sperm maturation, the distal centriole degenerates and only the proximal one remains at the cranial end of the connecting piece.

After fertilization, the connecting piece disassembles, the proximal centriole duplicates and recruits pericentriolar material from the 
Table 2 Intracytoplasmic sperm injection (ICSI) outcome in globozoospermia and acrosomal hypoplasia

\begin{tabular}{|c|c|c|c|}
\hline Author & Number of patients (cycles) & Fertilization rate & Results \\
\hline Dirican et al.. ${ }^{103} 2008$ & 2 globozoospermic brothers (1 ICSI cycle each) & $\begin{array}{l}\text { First cycle, } 33 \% \text {, with } \mathrm{Cl} \\
\text { Second cycle, } 9.1 \% \text {, without } \mathrm{Cl}\end{array}$ & $\begin{array}{l}\text { XX live birth, } 38 \text { weeks } \\
\text { XX live birth, } 38 \text { weeks }\end{array}$ \\
\hline Tejera et al.., ${ }^{104} 2008$ & 1 globozoospermic man (1 ICSI cycle) & $\begin{array}{l}\text { With Cl, 55.6\% } \\
\text { Without } \mathrm{Cl}, 35.7 \%\end{array}$ & $\begin{array}{l}\text { XX live birth, } 40 \text { weeks } \\
\text { Without transfer }\end{array}$ \\
\hline Kyono et al., ${ }^{105} 2009$ & 1 globozoospermic man (1 ICSI cycle) & With $\mathrm{Cl}, 88.2 \%$ & XX live birth 40 weeks \\
\hline Banker et al., ${ }^{106} 2009$ & 2 globozoospermic patients (2 ICSI cycles each) & $\begin{array}{l}\text { First patient, } 2 \text { cycles. } \\
\text { Without } \mathrm{Cl}(30.7 \% \text { and } 28.6 \%) \\
\text { Second patient, } 2 \text { cycles. } \\
\text { Without } \mathrm{Cl}(20 \% \text { and } 12.5 \%)\end{array}$ & $\begin{array}{l}\text { Without pregnancy } \\
\text { Miscarriage ( } 5 \text { weeks) } \\
\text { Without pregnancy } \\
\text { XY live birth, } 37 \text { weeks }\end{array}$ \\
\hline Egashira et al., ${ }^{107} 2009$ & 1 globozoospermic man (2 ICSI cycles) & $\begin{array}{l}\text { Without electrical activation, } 0 \% \\
\text { With electrical activation, 100\% }\end{array}$ & $\begin{array}{l}\text { Without transfer } \\
\text { XX live birth, } 37 \text { weeks }\end{array}$ \\
\hline Taylor et al., ${ }^{108} 2010$ & 1 globozoospermic man (ICSI cycle) & With $\mathrm{Cl}, 100 \%$ & $\begin{array}{l}\text { Ongoing pregnancy } \\
7 \text { weeks }\end{array}$ \\
\hline Sermondade et al., ${ }^{109} 2011$ & $\begin{array}{l}1 \text { man w/acrosomal hypoplasia (1 ICSI } \\
\text { cycle; spermatozoa selected by IMSI) }\end{array}$ & $\begin{array}{l}\text { Without } \mathrm{Cl}, 60 \% \\
\text { With } \mathrm{Cl}, 66 \%\end{array}$ & $\begin{array}{l}\text { XY live birth, } 38 \text { weeks } \\
\text { Without transfer }\end{array}$ \\
\hline
\end{tabular}

Abbreviations: $\mathrm{Cl}, \mathrm{Ca}^{++}$ionophore; IMSI, intracytoplasmic injection of morphologically selected spermatozoa.

oocyte cytoplasm, to become later the zygote centrosome from which the first mitotic spindle of the zygote originates.

In recent years, a number of reports have called the attention to the neck region, and in particular to the pathologies of the sperm centrosome as responsible for infertility in males. The concept of 'Ciliopathies' has been introduced for a series of syndromes with abnormal centriolar functioning, among them the immotile cilia syndrome' affecting sperm flagella and respiratory cilia. ${ }^{50,51}$ A number of authors have described sperm centrosomal abnormalities as a cause of fertilization failure, abnormal embryonic development or early pregnancy loss in patients with oligo, terato or globozoospermia. ${ }^{52-56}$ The use of heterologous ICSI (human spermatozoa injected into bovine oocytes) is very useful to explore the capacity of spermatozoa from infertile men to organize microtubules and elicit aster development after oocyte penetration. ${ }^{57,58}$

A human syndrome has been reported with predominance of decapitated or acephalic spermatozoa. These are sometimes wrongly denominated 'pin head' spermatozoa and appear as isolated, headless tails with normally developed mid-pieces or small globular drops of residual cytoplasm. ${ }^{59-64}$ In further studies, we have described, coexisting with acephalic forms, other spermatozoa with heads implanted laterally at varying angles in the mid-piece (abaxial implantations, Figure 5). In these cases, abnormal head-tail junctions are unusually fragile and frequently result in head tail separation. ${ }^{49,65}$ Ultrastructural studies have demonstrated that headless flagella and abnormal head-tail connections frequently contain proximal centrioles and connecting pieces of normal configuration. Loose heads are rarely found in semen. Studies on testicular biopsies have demonstrated that the alterations result from abnormal migration of the centriole-tail complex that completely fails to join the spermatid nucleus or aberrantly attaches to it in a lateral position, giving rise to either acephalic forms or spermatozoa with misalignment of head and mid-pieces (Figure 5). ${ }^{49}$ Family clustering has been reported among these patients indicating that this distinctive phenotype is a centrosome-related primary sperm defect that results from an abnormal spermatogenic programming of genetic origin. ${ }^{49,66}$ Recent studies have identified a mice phenotype with sperm decapitation due to mutations in the centrobin and IFT88 genes, that code for two sperm centriole-related proteins. ${ }^{67,68}$ There are no current communications of similar mutations in humans.

The fact that sperm centrioles are structurally normal in these patients prompted investigations toward the identification of functional centriolar deficiencies. Heterologous ICSI studies injecting human spermatozoa with abnormal head-tail attachments result in failure to develop sperm asters within bovine oocytes, which indicates that the microtubule organizing capacity of these sperm centrioles is seriously affected. ${ }^{69}$ What impaired mechanisms can account for centrosomal dysfunction in spermatozoa with defective head-tail relationships? Considering that proteasomes have been localized near the centrosome in the neck region of human spermatozoa, ${ }^{70}$ we hypothesized that they could be involved in post-fertilization release of the proximal centriole by proteolysis of the connecting piece and decided to investigate their possible involvement in the mechanisms of centriolar dysfunction. A significant reduction was found in the activity of two proteasomal enzymes in spermatozoa with abnormal head-tail attachments. ${ }^{56,71}$ Further in vitro experiments involving pharmacologic or immunologic neutralization of sperm proteasomes have resulted in failure of sperm aster formation and syngamy after sperm microinjection of human spermatozoa in bovine oocytes. These findings support our contention that insufficient function of centriole-associated proteasomes of the sperm neck region is probably responsible for centrosomal dysfunction in this syndrome. ${ }^{56}$

The first ICSI to be reported in patients with abnormal sperm headtail attachment resulted in fertilization and pronuclear formation in all oocytes, but syngamy did not take place and all zygotes degenerated. ${ }^{49}$ This outcome was confirmed by later reports. ${ }^{69,72}$ Since then, there have been a few successful pregnancies by microinjection of these spermatozoa rigorously selected to avoid abnormalities of the head-neck junction (unpublished data). ${ }^{73-75}$ These disimilar results indicate variations in the degree of abnormalities of the head-neck junction, some of them compatible with normal centrosomal function.

There is a growing interest in the identification of other types of anomalies arising from centriole-centrosomal malfunction. This interest is nourished by the prospects of development of methods for the treatment of fertilization failure due to sperm centrosomal anomalies. ${ }^{76,77}$

\section{PATHOLOGIES OF THE SPERM MID-PIECE AND TAIL}

\section{Mitochondrial anomalies of the mid-piece}

Among the many phenotypes responsible for abnormal sperm function, mitochondrial anomalies have received relatively little attention. Different kinds of mitochondrial alterations have been reported in asthenozoospermic men. ${ }^{78-82}$ These included numerical deficiencies, irregular organization, abnormally shorter or longer mitochondrial 


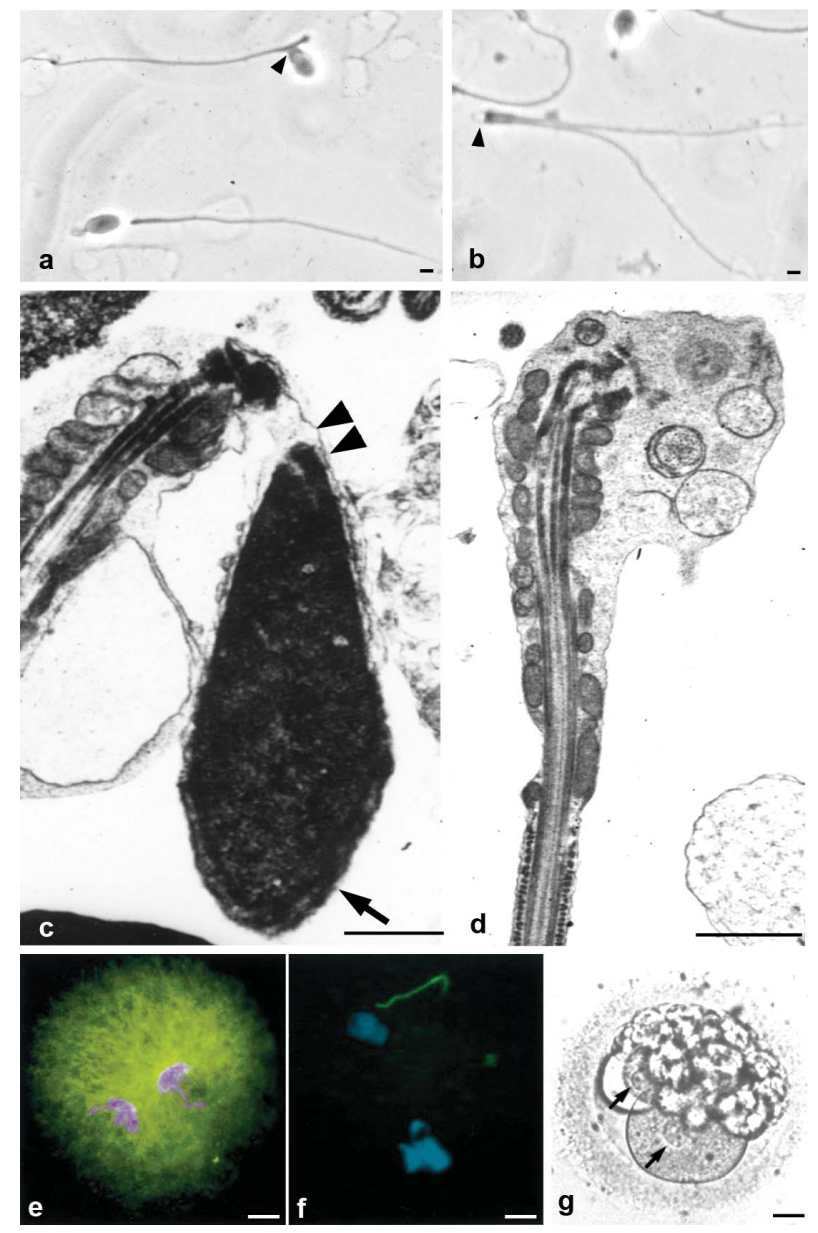

Figure 5 Pathologies of the sperm neck. (a, b) Sperm smear showing abnormal alignment of heads and tails (a, arrowhead) and acephalic spermatozoa (b, arrowhead). (c) Electron microscopy shows lack of attachment between head and mid-piece (double arrowhead) and normal acrosome (arrow). (d) Acephalic spermatozoon: absence of the head. The enlarged cephalic end is occupied by the mitochondrial sheath, connecting piece and vesicular structures. (e, f) Heterologous ICSI. (e) Normal pronuclear and aster formation (microtubules, green fluorescence) after injection of a normal human spermatozoon into a bovine oocyte. (f) When spermatozoa with abnormal head-mid-piece relationships are injected pronuclei form, but there is no aster development in the zygote. (g) Human ICSI failure after injection of spermatozoon with neck anomalies. Pronuclei are visible (arrows), but syngamy and cleavage did not occur and the zygote degenerated. Bars $=1 \mu \mathrm{m}(\mathbf{a}-\mathbf{d})$ and $20 \mu \mathrm{m}(\mathbf{e}-\mathbf{g})$. $\mathbf{g}$ is reproduced with permission from Chemes et al. ${ }^{49} \mathbf{e}$ and $\mathbf{f}$ are reproduced with permission from Rawe et al. ${ }^{69}$

sheaths, and increased matrix density or lipid inclusions. Mitochondrial anomalies of the sperm mid-piece are an infrequent form of sperm pathology usually resulting in severe asthenozoospermia. Reported results indicate that although mid-piece defects cause serious motility alterations and lower fertilization potential, this does not preclude fertilization, pregnancy and birth of healthy children when ICSI is used. ${ }^{82}$

The relatively poor attention that these anomalies have received probably reflects their very infrequent occurrence. This prevents further elaborations on their overall consequences on male fertility. The use of ICSI is probably the best therapy.

\section{Flagellar pathologies and motility disorders}

Defective sperm flagella are the principal cause of sperm motility disorders. There are two main forms of flagellar pathologies with different phenotypic characteristics and consequences for male fertility: non-specific flagellar anomalies (NSFAs) and various genetic disorders including primary ciliary diskinesia and the dysplasia of the fibrous sheath. ${ }^{83}$

NSFAs are the most frequent flagellar pathology in severe asthenozoospermia. High values of NSFA were present in $70 \%$ of 201 asthenozoospermic patients with 9.5\% progressive motility. ${ }^{83}$ Asthenozoospermia was of unknown origin or secondary to various andrological conditions including varicocele, orchitis, immunological infertility or infections of the reproductive tract. Affected flagella appeared normal in sperm smears because tail diameter was not modified. Ultrastructural examination disclosed random flagellar anomalies in the number (lack or duplication), location (dislocations, transpositions) and/or architectural organization of flagellar microtubules. These findings demonstrate that severe asthenozoospermia is mainly due to structural abnormalities of the tail, and have challenged the concept that most sperm motility disorders have a 'functional' basis. ${ }^{3,9}$ NSFA patients can experience improved sperm motility when etiological or empirical treatments are instituted, and may expect good fertility results either spontaneously or utilizing conventional methods or in vitro fertilization. In severe cases or when there is no response to treatments, ICSI has good prognosis and does not pose additional risks in view of the lack of recognized genetic components in this pathology. ${ }^{9}$

Significant sperm abnormalities of proven or suspected genetic origin are rare conditions responsible for extreme asthenozoospermia or total sperm immotility. Affected patients complain of male infertility and chronic respiratory disease, alterations caused by abnormal function of sperm flagella and respiratory cilia. Early investigations of the Scandinavian school disclosed subtle ultrastructural modifications in subcellular components of cilia and sperm axonemes that had not been previously identified because they were not apparent under light microscopic examination. ${ }^{51,84}$ These studies provided the biological basis for the understanding of the 'immotile cilia syndrome', denomination later changed to 'primary ciliary diskinesia' (PCD) to acknowledge the fact that partial or residual motility were sometimes present. ${ }^{85}$ In $50 \%$ of cases, PCD patients may have dextrocardia (situs inversus of the Kartagener syndrome), or other alterations in visceral rotation. It has been proposed that this may be due to immotility of fetal cilia, which would compromise lateral organ rotation in the embryo with chance alone determining whether organs take up their normal lateral position or the transposed one. ${ }^{86} \mathrm{~A}$ wide spectrum of anomalies has been described in PCD patients including total or partial deletion of dynein arms from sperm and ciliary axonemes, lack of the central microtubular pair, microtubular translocations, absence of the axoneme, etc. (Figure 6, reviewed in Ref. 3). Family transmission of PCD is due to various autosomic recessive mutations with extensive locus heterogeneity. Involved proteins include heavy chain dyneins, microtubule dynein binding proteins, or components of the central pair microtubules both in humans and mice models that express PCDlike phenotypes. ${ }^{87-92}$

Important disturbances in other sperm cytoskeletal components, notably the fibrous sheath, have been reported in men with dysplasia of the fibrous sheath (DFS, reviewed in Ref. 3), ${ }^{8,9,83}$ a likely variant of PCD in which widespread disarray of the sperm fibrous sheath coexists with the classical PCD axonemal defects in cilia and flagella. ${ }^{83}$ Affected spermatozoa exhibit short, thick and irregular tails with bulky and disorganized fibrous sheaths surrounding variably distorted axonemes sometimes missing the central pair or dynein arms (Figure 6). Lack of migration of the annulus, absence of mitochondria at the mid-piece 


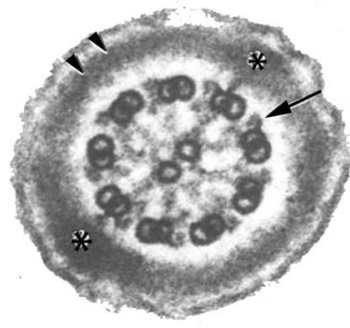

a
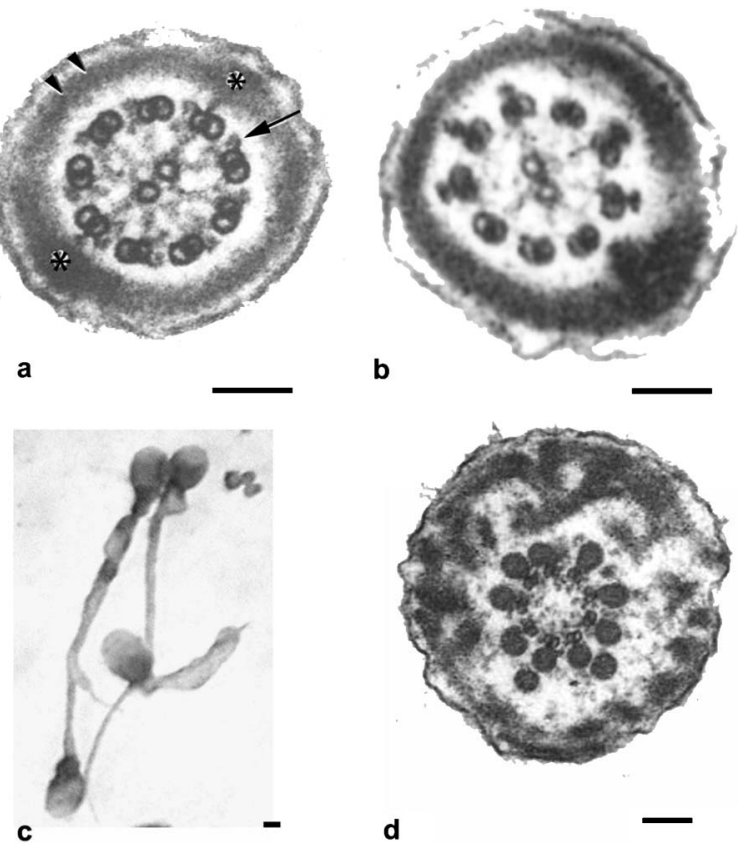

d

Figure 6 Flagellar pathologies. (a) Transverse section of a normal sperm principal piece. The classical $9+2$ structure of the axoneme is clearly seen. Note dynein arms (arrow) and normal fibrous sheath (asterisks and double arrow). (b) Lack of dynein arms in microtubular doublets of immotile spermatozoon in a patient with primary ciliary dyskinesia. (c, d) Dysplasia of the fibrous sheath. Tails are short, thick and of irregular profile (c). Ultrastructural examination depicts thickened fibrous sheath and the absence of the central microtubules of the axoneme. Bars $=0.1 \mu \mathrm{m}$ ( $\mathbf{a}, \mathbf{b}$ and $\mathbf{d}$ ) and $0.5 \mu \mathrm{m}$ (c). Flagellar diameter is $0.4 \mu \mathrm{m}$ ( $\mathbf{a}$ and $\mathbf{b}$ ) and $0.7 \mu \mathrm{m}(\mathbf{d})$. $\mathbf{a}$ is reproduced with permission from Turner et al. ${ }^{93}$ Figure $6 \mathrm{~d}$ is reproduced with permission from Chemes et al. ${ }^{9}$

and alterations in the outer dense fibers suggest that this syndrome very likely corresponds to dysplastic development of the whole sperm tail cytoskeleton during testicular spermiogenesis. There is family clustering among 20\% of DFS patients and the condition is most probably of genetic origin. However, no modifications in genes coding for flagellar proteins such as AKAP4, heavy chain dyneins or spermspecific thioredoxins have been reported to date, with the possible exception of an isolated AKAP4 gene and protein deletion in one out of five DFS patients. ${ }^{12,93,94}$ It is likely that DFS is a multigenic disease caused by alterations in several different gene products (reviewed in Ref. 3). Analysis of the family trees suggests recessive autosomic inheritance. The sperm phenotype does not change in time and is not modified by medical therapies. There are no reports of natural conceptions and classical in vitro fertilization methods fail in achieving fertilizations-pregnancies.

The introduction of ICSI has revolutionized fertility prognosis in severe asthenozoospermia or total sperm immotility. Microinjection of spermatozoa from patients suffering from PCD or DFS results in normal rates of fertilization and implantation, and many births of healthy babies have been reported (Table 3, reviewed in Ref. 3). It had been previously reported that severe motility disorders prevented ICSI success, but careful reading of the literature indicates that failures were due to necrozoospermia rather than to asthenozoospermia as was also noted by the authors. ${ }^{95,96}$

The main concern that remains in the treatment of PCD and DFS patients is the potential transmission to the offspring. This should be disclosed to patients and informed consent requested before proceeding to ICSI. Provided that there is no chronic respiratory disease, DFS patients are prepared to accept the risk when infertility is the only possible consequence, with the understanding that likely developments of better treatments will solve the problem for their male children in the future. There are no reports of respiratory difficulties in babies born from DFS fathers, and fertility assessment in the male progeny will only be possible in the next two decades. No comprehensive investigations on these possibilities are available to date. It has been noted that there is a striking contrast between the high incidence of DFS and low incidence of PCD in a South American population of multiethnic origin, ${ }^{12}$ which may indicate the interaction between genetic and environmental influences in the generation of this phenotype.

\section{FERTILITY POTENTIAL IN TERATO- AND ASTHENOZOOSPERMIA}

In recent years, new methods have been introduced for the treatment of specific sperm deficiencies. They include identification and negative selection of spermatozoa carrying nuclear 'vacuoles' or hypoplastic acrosomes by high-resolution microscopy, stimulation of oocyte activation or sperm motility in cases of deficient acrosomal function or sperm immotility and selection by annexin columns or hyaluronic acid binding for increased rates of DNA fragmentation. Application of these therapies necessarily depends on the previous identification of specific phenotypes or abnormal mechanisms underlying different sperm pathologies. This is why an adequate diagnosis of teratozoospermia that goes beyond the recognition of abnormal sperm shapes is so important for the advancement in new therapies for severe male factor infertility.

As previously indicated, chromatin and acrosomal sperm anomalies are the most frequent alterations in severe teratozoospermia. The introduction of real-time sperm selection by high-resolution light microscopy in the embryology laboratory to avoid microinjection of 'vacuolated' spermatozoa (IMSI) has been advocated by some groups that have reported better embryo quality, higher implantation and pregnancy rates and lower pregnancy losses, but this technique has not gained universal acceptance, and negative results have also been communicated (Table 1). ${ }^{26-28,97-102}$ As stated above, we believe that nuclear 'vacuoles' correspond to the serious deficiencies in chromatin condensation and have already been described in a previous section. When considering the use of spermatozoa carrying acrosomal anomalies, recent studies have attempted to compensate for perinuclear theca deficiencies that cause inadequate $\mathrm{Ca}^{++}$fluctuations. Oocyte activation has been achieved using $\mathrm{Ca}^{++}$ionophore (CI), strontium or electrical activation, which has resulted in pregnancies and live births (Table 2). ${ }^{47,103-109}$ A novel approach has been the use of

Table 3 Intracytoplasmic sperm injection (ICSI) outcome with immotile spermatozoa

\begin{tabular}{|c|c|c|c|c|}
\hline & $\begin{array}{l}\text { Number of } \\
\text { patients }\end{array}$ & $\begin{array}{l}\text { Fertilization } \\
\text { rate (\%) }\end{array}$ & $\begin{array}{c}\text { Pregnancies/ } \\
\text { miscarriage }\end{array}$ & Outcome \\
\hline $\begin{array}{l}\text { Primary ciliary } \\
\text { dyskinesia/ } \\
\text { immotile cilia } \\
\text { syndrome }^{\text {a }}\end{array}$ & 11 & $54 \pm 12$ & $5 / 1$ & 7 live births \\
\hline $\begin{array}{l}\text { DFS/stump tails/ } \\
\text { short tails }^{\mathrm{b}}\end{array}$ & 12 & $63 \pm 16$ & $10 / 2$ & 14 live births \\
\hline
\end{tabular}

This table is reproduced with permission from Chemes et al. ${ }^{3}$

${ }^{a}$ Data from Bongso et al.; ${ }^{110}$ Cayan et al.; ${ }^{111}$ Gallo et al.; ${ }^{112}$ Kamal et al.; ${ }^{113}$

Papadimas et al.; ${ }^{114}$ von Zumbusch et al. ${ }^{115}$

${ }^{\mathrm{b}}$ Data from Brugo Olmedo et al.; ${ }^{116,117}$ Favero et al.; ${ }^{118}$ Stalf et al. ${ }^{119}$ 
IMSI to identify and avoid microinjection of spermatozoa with hypoplastic acrosomes.

There is a high incidence of chromatin and acrosome anomalies in patients with strict morphology values below $4 \%$ and predominance of amorphous spermatozoa. As we have already noted, these alterations can be responsible for repeated ICSI failures or early pregnancy loss. If this is the case, and a female factor can be ruled out, we advise ultrastructural studies of spermatozoa to search for these abnormalities. All new developments addressed at identifying and avoiding the use of defective spermatozoa will probably result in better fertility prognosis.

As previously discussed, spermatozoa with deficiencies in the headneck attachment frequently fail to proceed beyond the pronuclear stage due to insufficient sperm aster formation and failure of cleavage. Successful pregnancies have been obtained microinjecting spermatozoa carefully selected to avoid head and tail misalignments (reviewed in Ref. 3). Defects of the sperm neck are much less frequent than chromatin or acrosome abnormalities.

Before the advent of ICSI, asthenozoospermia was one of the leading causes of fertility failure because immotile spermatozoa were unable to reach the oocyte and penetrate normally. The situation changed dramatically after the introduction of sperm microinjection. Numerous reports in the literature inform on successful pregnancies and live births after injection of immotile (live) spermatozoa in 23 patients suffering from PCD or DFS. Even though fertilization rates were somewhat low, 15 pregnancies were established and 21 healthy babies were born, with only three miscarriages (Table 3). ${ }^{9,110-119}$ Various techniques have been introduced to overcome the difficulties in distinguishing between dead (immotile) spermatozoa and immotile (but viable) forms. The hypo-osmotic swelling test, the stimulation of motility with pentoxyfilline and even non-contact diode laser has been used to distinguish between total sperm immotility and necrozoospermia with variable success. ${ }^{120-123}$

There have been reports of other techniques for sperm selection in cases of increased rates of DNA fragmentation. These include spermatozoa bound to hyaluronic acid or selected by annexin columns. These methods are beyond the limits of this work because, as stated before, there is no clear correlation between the prevalence of specific sperm anomalies and higher DNA fragmentation values.

We should end by stressing that a correct diagnosis of sperm abnormalities that identifies defective mechanisms involved sets the grounds for an evidence-based treatment of severe male factor infertility.

\section{COMPETING FINANCIAL INTERESTS}

The authors declare no competing financial interests.

\section{ACKNOWLEDGMENTS}

The expression 'Tales of the tail...' in the title of this article was inspired by a conference given by Stuart Moss, $\mathrm{PhD}$, at a North American Testis Workshop in California, USA. There is also a paper by R. Turner with some title similarities (J Androl 2003; 24: 790-803). The Journal of Andrology did not consider the partial use of the title an infringement of their copyrights.

1 Kruger TF, Menkveld R, Stander FS, Lombard CJ, van der Merwe JP et al. Sperm morphologic features as a prognostic fractor in in vitro fertilization. Fertil Steril 1986; 46: 1118-23.

2 WHO. WHO Laboratory Manual for the Examination and Processing of Human Semen. 5th ed. Geneva: WHO Press; 2010.
3 Chemes HE, Rawe VY. Sperm pathology: a step beyond descriptive morphology. Origin, characterization and fertility potential of abnormal sperm phenotypes in infertile men. Hum Reprod Update 2003; 9: 405-28.

4 Balhorn R. A model for the structure of chromatin in mammalian sperm. J Cell Biol 1982; 93: 298-305.

5 Oliva R. Protamines and male infertility. Hum Reprod Update 2006; 12: 417-35.

6 Haraguchi CM, Mabuchi T, Hirata S, Shoda T, Tokumoto T et al. Possible function of caudal nuclear pocket: degradation of nucleoproteins by ubiquitin-proteasome system in rat spermatids and human sperm. J Histochem Cytochem 2007; 55 585-95.

7 Westbrook VA, Diekman AB, Naaby-Hansen S, Coonrod SA, Klotz KL et al. Differentia nuclear localization of the cancer/testis-associated protein, SPAN-X/CTp11, in transfected cells and in 50\% of human spermatozoa. Biol Reprod 2001; 64:345-58.

8 Chemes H, Brugo Olmedo S, Zanchetti F, Carrere C, Lavieri JC. Dysplasia of the fibrous sheath. An ultrastructural defect of human spermatozoa associated with sperm immotility and primary sterility. Fertil Steril 1987; 48: 664-9.

9 Chemes $\mathrm{H}$, Brugo Olmedo SB, Carrere C, Oses R, Carizza C. Ultrastructural pathology of the sperm flagellum. Association between flagellar pathology and fertility prognosis in severely asthenozoospermic men. Hum Reprod 1998; 13: 2521-6.

10 Holstein AF. Morphologische studien an abnormen spermatiden und spermatozoen des menschen. Virchows Arch 1975; 367: 93-112.

11 Zamboni L. The ultrastructural pathology of the spermatozoon as a cause of infertility: The role of electron microscopy in the evaluation of semen quality. Fertil Steril 1987 . 48: 711-34.

12 Chemes $\mathrm{H}$. Phenotypes of sperm pathology: genetic and acquired forms in infertile men. J Androl 2000; 21: 799-808.

13 Francavilla S, Bianco MA, Cordeschi G, D'Abrizio P, de Stefano C et al. Ultrastructural analysis of chromatin defects in testicular spermatids in azoospermic men submitted to TESE-ICSI. Hum Reprod 2001; 16: 1440-8.

14 Baccetti C, Collodel G, Piomboni P. Apoptosis in human ejaculated sperm cells. J Submicrosc Cytol Pathol 1996; 28: 587-96.

15 Muratori M, Piomboni P, Baldi E, Filimberti E, Pecchioli P et al. Functional and structural features of DNA-fragmented human sperm. J Androl 2000; 21: 903-12.

16 Alvarez Sedó C, Lavolpe M, Uriondo H, Papier S, Nodar F et al. Nuclear vacuoles and apoptosis markers after Annexin $\mathrm{V}$ columns in patients with severe teratozoospermia. Fertil Steril 2011; 96: S159-60.

17 Balhorn R, Reed S, Tanphaichitr N. Aberrant protamine 1/protamine 2 ratios in sperm of infertile human males. Experientia 1988; 44: 52-5.

18 Blanchard Y, Lescoat D, Le Lannou D. Anomalous distribution of nuclear basic proteins in round-headed human spermatozoa. Andrologia 1990; 22: 549-55.

19 de Yebra L, Ballesca JL, Vanrell JA, Corzet M, Balhorn R et al. Detection of P2 precursors in the sperm cells of infertile patients who have reduced protamine P2 levels. Fertil Steril 1998; 69: 755-9.

20 Bench G, Corzett MH, de Yebra L, Oliva R, Balhorn R. Protein and DNA contents in sperm from an infertile human male possessing protamine defects that vary over time. Mol Reprod Dev 1998; 50: 345-53.

21 Emery BR, Carrell DT. The effect of epigenetic sperm abnormalities on early embrygenesis. Asian J Androl 2006; 8: 131-42.

22 Aoki VW, Liu L, Carrell DT. Identification and evaluation of a novel sperm protamine abnormality in a population of infertile males. Hum Reprod 2005; 20: 1298-306.

23 Rhim JA, Connor W, Dixon GH, Harendza CJ, Evenson DP et al. Expression of an avian protamine in transgenic mice disrupts chromatin function in spermatozoa. Biol Reprod 1995; 52: 20-32.

24 Wu JY, Ribar TJ, Cummings DE, Burton KA, McKnight GS et al. Spermiogenesis and exchange of basic nuclear proteins are impaired in male germ cells lacking Camk4. Nat Genet 2000; 25: 448-52

25 Yu YE, Zhang Y, Unni E, Shirley CR, Deng JM et al. Abnormal spermatogenesis and reduced fertility in transition nuclear protein 1-deficient mice. Proc Natl Acad Sci USA 2000; 97: 4683-8.

26 Bartoov B, Berkovitz A, Eltes F. Selection of spermatozoa with normal nuclei to improve the pregnancy rate with intracytoplasmic sperm injection. $N$ Eng/ J Med 2001; 345: 1067-8.

27 Bartoov B, Berkovitz A, Eltes F, Kogosovsky A, Menezo Y et al. Real-time fine morphology of motile human sperm cells is associated with IVF-ICSI outcome I Androl 2002; 23: 1-8.

28 Bartoov B, Berkovitz A, Eltes F, Kogosovsky A, Yagoda A et al. Pregnancy rates are higher with intracytoplasmic morphologically selected sperm injection than with conventional intracytoplasmic injection. Fertil Steril 2003; 80: 1413-9.

29 Kierszenbaum AL, Tres LL. The acrosome-acroplaxome-manchette complex and the shaping of the spermatid head. Arch Histol Cytol 2004; 67: 271-84.

30 Schirren CG, Holstein AF, Schirren C. Über die morphogenese rundköpfiger spermatozoen des menschen. Andrologie 1971; 3: 117-25.

31 Holstein AF, Schirren C, Schirren CG. Human spermatids and spermatozoa lacking acrosomes. J Reprod Fertil 1973; 35: 489-91.

32 Bisson JP, David G, Magnin C. Etude ultrastructurale des anomalies d lácrosome dans les spermatozoide a tete irreguliere. Bull Ass Anat (Nancy) 1975; 59: 345-6.

33 Baccetti B, Renieri T, Rosati F, Selmi MG, Casanova S. Further observations on the morphogenesis of the round headed human spermatozoa. Andrologia 1977; 9: 25564

34 Nistal M, Herruzo A, Sanchez Corral F. Teratozoospermia absoluta de presentación familiar: espermatozoides microcéfalos irregulares sin acrosoma. Andrologia 1978; 10: $234-40$. 
35 Florke-Gerloff S, Topfer-Petersen E, Muller-Esterl W, Mansouri A, Schatz R et al. Biochemical and genetic investigation of round-headed spermatozoa in infertile men including two brothers and their father. Andrologia 1984; 16: 187-202.

36 Anton-Lampretch I, Kotsur B, Schopf E. On round headed human spermatozoa. Fertil Steril 1976; 27: 685-93.

37 Escalier D. Failure of differentiation of the nuclear-perinuclear skeletal complex in the round-headed human spermatozoa. Int J Dev Biol 1990; 34: 287-97.

38 Oko R, Aul RB, Wu A, Sutovsky P. The sperm head cytoskeleton. In: Robaire B, Chemes $\mathrm{HE}$, Morales C, editors. Andrology in the 21st Century. Englewood, NJ: Medimond Publishing Company; 2001. pp37-51.

39 Alvarez Sedó C, Sutovsky P, Oko R, Rawe VY, Chemes HE. Biogenesis of the sperm perinuclear theca during human spermiogenesis. Fertil Steril 2009; 92: 1472-3.

40 Baccetti B, Capitani S, Collodel G, Di Cairano G, Gambera L et al. Genetic sperm defects and consanguinity. Hum Reprod 2001; 16: 1365-71.

41 Koscinski I, Elinati E, Fossard C, Redin C, Muller J et al. DPY19L2 deletion as a major cause of globozoospermia. Am J Hum Genet 2011; 88: 344-50.

42 Harbuz R, Zouari R, Pierre V, Ben Khelifa M, Kharouf M et al. A recurrent deletion of DPY19L2 causes infertility in man by blocking sperm head elongation and acrosome formation. Am J Hum Genet 2011; 88: 351-61.

43 Parrington J, Swann K, Shevchenko VI, Sesay AK, Lai FA. Calcium oscillations in mammalian eggs truggered by a soluble sperm protein. Nature $1996 ; 379$ : 364-8.

44 Sutovsky P, Manandhar G, Wu A, Oko R. Interactions of sperm perinuclear theca with the oocyte: implications for oocyte activation, anti-polyspermy defense and assisted reproduction. Microsc Res Tech 2003; 61: 362-78.

45 Ito C, Yamatoya K, Yoshida K, Kyono K, Yao R et al. Appearance of an oocyte activation-related substance during spermatogenesis in mice and humans. Hum Reprod 2010; 25: 2734-44.

46 Bos-Mikich A, Whittingham DG, Jones KT. Meiotic and mitotic $\mathrm{Ca}^{2+}$ oscillations affect cell composition in resulting blastocysts. Dev Biol 1997; 182: 172-9.

47 Yanagida K, Katayose H, Hayashi S, Sato A. Successful pregnancy after ICSI with strontium oocyte activation in low rates of fertilization. Reprod Biomed Online 2006; 13: 801-6.

48 Holstein AF, Roosen-Runge EC. Atlas of Human Spermatogenesis. Berlin: Grose Verlag; 1981.

49 Chemes HE, Puigdomenech ET, Carizza C, Brugo Olmedo S, Zanchetti F et al. Acephalic spermatozoa and abnormal development of the head-neck attachment. A human syndrome of genetic origin. Hum Reprod 1999; 14: 1811-8.

50 Tammachote R, Hommerding CJ, Sinders RM, Miller CA, Czarnecki PG et al. Ciliary and centrosomal defects associated with mutation and depletion of the Meckel syndrome genes MKS1 and MKS3. Hum Mol Genet 2009; 18: 3311-23.

51 Afzelius BA, Eliasson R, Johnsen O, Lindholmer C. Lack of dynein arms in immotile human spermatozoa. J Cell Biol 1975; 66: 225-32.

52 Sathananthan AH. Functional competence of abnormal spermatozoa. Baillieres Clin Obstet Gynaecol 1994; 8: 141-56.

53 Sathananthan AH, Ratnasooriya WD, de Silva PK, Menezes J. Characterization of human gamete centrosomes for assisted reproduction. Ital J Anat Embryol 2001; 106 (Suppl 2): 61-73.

54 van Blerkom J. Sperm centrosome dysfunction: a possible new class of male factor infertility in the human. Mol Hum Reprod 1996; 2: 349-54.

55 Nakamura S, Terada Y, Horiuchi T, Emuta C, Murakami T et al. Analysis of the human sperm centrosomal function and the oocyte activation ability in a case of globozoospermia, by ICSI into bovine oocytes. Hum Reprod 2002; 17: 2930-34.

56 Rawe VY, Díaz ES, Abdelmassih R, Wójcik C, Morales $\mathrm{P}$ et al. The role of sperm proteasomes during sperm aster formation and early zygote development: implications for fertilization failure in humans. Hum Reprod 2008; 23: 573-80.

57 Terada Y, Nakamura S, Hewitson L, Simerly CR, Horiuchi T et al. Human sperm aster formation after intracytoplasmic sperm injection with rabbit and bovine eggs. Fertil Steril 2002; 77: 1283-4.

58 Terada Y, Nakamura S, Simerly C, Hewitson L, Murakami T et al. Centrosomal function assessment in human sperm using heterologous ICSI with rabbit eggs: a new male factor infertility assay. Mol Reprod Dev 2004; 67: 360-5.

59 Zaneveld LJ, Polakoski KL. Collection and physical examination of the ejaculate. In: Hafez ESE, editor. Techniques of Human Andrology. Amsterdam: Elsevier North Holland Biomedical Press; 1977. pp147-72.

60 LeLannou D. Teratozoospermie consistant en läbsence de tete spermatique par defaut de conexión. J Gynecol Obstet Biol Reprod (Paris) 1979; 8: 43-5.

61 Perotti ME, Giarola A, Gioria M. Ultrastructural study of the decapitated sperm defect in an infertile man. J Reprod Fertil 1981; 63: 543-9.

62 Perotti ME, Gioria M. Fine structure and morphogenesis of "headless" human spermatozoa associated with infertility. Cell Biol Int Rep 1981; 5: 113

63 Baccetti B, Selmi MG, Soldani P. Morphogenesis of "decapitated spermatozoa" in a man. J Reprod Fertil 1984; 70: 395-7.

64 Chemes HE, Carizza C, Scarinci F, Brugo Olmedo S, Neuspiler N et al. Lack of a head in human spermatozoa from sterile patients: a syndrome associated with impaired fertilization. Fertil Steril 1987; 47: 310-6.

65 Kamal A, Mansour R, Fahmy I, Serour G, Rhodes C et al. Easily decapitated spermatozoa defect: a possible cause of unexplained infertility. Hum Reprod 1999; 14: 2791-5.

66 Baccetti B, Burrini AG, Collodel G, Magnano AR, Piomboni P et al. Morphogenesis of the decapitated and decaudated sperm defect in two brothers. Gamete Res 1989; 23 : 181-8.
67 Liska F, Gosele C, Rivkin E, Tres L, Cardoso MC et al. Rat hd mutation reveals an essential role of centrobin in spermatid head shaping and assembly of the head-tail coupling apparatus. Biol Reprod 2009; 81: 1196-205.

68 Kierszenbaum AL, Rivkin E, Tres LL, Yoder BK, Haycraft CJ et al. GMAP210 and IFT88 are present in the spermatid Golgi apparatus and participate in the development of the acrosome-acroplaxome complex, head-tail coupling apparatus and tail. Dev Dyn 2011; 240: 723-36.

69 Rawe VY, Terada Y, Nakamura S, Chillik C, Brugo Olmedo S et al. A pathology of the sperm centriole responsible for defective sperm aster formation, syngamy and cleavage. Hum Reprod 2002; 17: 2344-9.

70 Wójcik C, Benchaib M, Lornage J, Czyba JC, Guerin JF. Proteasomes in human spermatozoa. Int J Androl 2000; 23: 169-77.

71 Morales P, Diaz ES, Pizarro E, Rawe VY, Chemes HE. Decreased proteasome enzymatic activity in sperm from patients with genetic abnormalities of the headtail junction and acephalic spermatozoa. J Androl 2004; 25: 41.

72 Saias-Magnan J, Metzler-Guillemain C, Mercier G, Carles-Marcorelles F, Grillo JM et al. Failure of pregnancy after intracytoplasmic sperm injection with decapitated spermatozoa: case report. Hum Reprod 1999; 14: 1989-92.

73 Porcu G, Mercier G, Boyer P, Achard V, Banet J et al. Pregnancies after ICSI using sperm with abnormal head-tail junction from two brothers: case report. Hum Reprod 2003; 18: 562-7.

74 Emery BR, Thorp C, Malo JW, Carrell DT. Pregnancy from intracytoplasmic sperm injection of a sperm head ad detached tail. Fertil Steril 2004; 81: 686-8.

75 Gambera L, Falcone P, Mencaglia L, Collodel G, Serafini F et al. Intracytoplasmic sperm injection and pregnancy with decapitated sperm. Fertil Steril 2010; 93. 1347.e7-12.

76 Nakamura S, Terada Y, Rawe VY, Uehara S, Morito Y et al. A trial to restore defective human sperm centrosomal function. Hum Reprod 2005; 20: 1933-7.

77 Terada Y, Schatten G, Hasegawa H, Yaegashi N. Essential roles of the sperm centrosome in human fertilization: developing the therapy for fertilization failure due to sperm centrosomal dysfunction. Tohoku J Exp Med 2010; 220: 247-58.

78 Wilton LJ, Temple-Smith PD, de Kretser DM. Quantitative ultrastructural analysis of sperm tails reveals flagellar defects associated with persistent asthenozoospermia. Hum Reprod 1992; 7: 510-6.

79 Folgero T, Bertheussen K, Lindal S, Torbergsen T, Oian P. Mitochondrial disease and reduced sperm motility. Hum Reprod 1993; 11: 1863-8.

80 Mundy AJ, Ryder TA, Edmonds DK. Asthenozoospermia and the human sperm midpiece. Hum Reprod 1995; 10: 116-9.

81 Sauvalle A, Le Bris C, Izard J. Supernumerary microtubules and prolongation of the middle piece in two infertile patients. Int J Fertil 1983; 28: 173-6.

82 Rawe VY, Hermes R, Nodar FN, Fiszbain G, Chemes HE. Results of intracytoplasmic sperm injection in two infertile patients with abnormal organization of sperm mitochondrial sheaths and severe asthenoteratozoospermia. Fertil Steril 2007; 88: 649-53.

83 Chemes HE. The significance of flagellar pathology in the evaluation of abnormal sperm motility. In: Baccetti B, editor. Comparative Spermatology 20 Years after (Serono Symposia Publications from Raven Press). Vol. 75. New York: Raven Press; 1991. pp 815-9.

84 Pedersen $\mathrm{H}$, Rebbe $\mathrm{H}$. Absence of arms in the axoneme of immotile human spermatozoa. Biol Reprod 1975; 12: 541-4.

85 Rossman CM, Forrest JB, Less RM, Newhouse AF, Newhouse MT. The dyskinetic cilia syndrome: abnormal ciliary motility in association with abnormal ciliary ultrastructure. Chest 1981; 80: 860-5.

86 Afzelius BA. A human syndrome caused by immotile cilia. Science 1976; 193: 317

87 Pennarun G, Escudier E, Chapelin C, Bridoux AM, Cacheux V et al. Loss-of-function mutations in a human gene related to Chlamydomonas reinhardtii dynein IC78 result in primary ciliary dyskinesia. Am J Hum Genet 1999; 65: 1508-19.

88 Blouin JL, Meeks M, Radhakrishna U, Sainsbury A, Gehring C et al. Primary ciliary dyskinesia: a genome-wide linkage analysis reveals extensive locus heterogeneity. Eur $J$ Hum Genet 2000; 8: 109-18.

89 Bartoloni L, Blouin JL, Pan Y, Gehrig C, Maiti AK et al. Mutations in the DNAH11 (axonemal heavy chain dynein type 11 ) gene cause one form of situs inversus totalis and most likely primary ciliary dyskinesia. Proc Natl Acad Sci USA 2002; 99: 10282-

90 Olbrich H, Haffner K, Kispert A, Volkel A, Volz A et al. Mutations in DNAH5 cause primary ciliary dyskinesia and randomization of left-right asymmetry. Nat Genet 2002; 30: 143-4.

91 Ibanez-Tallon I, Gorokhova S, Heintz N. Loss of function of axonemal dynein Mdnah5 causes primary ciliary dyskinesia and hydrocephalus. Hum Mol Genet2002; 11: 71521

92 Sapiro R, Kostetskii I, Olds-Clarke P, Gerton GL, Radice GL et al. Male infertility, impaired sperm motility, and hydrocephalus in mice deficient in sperm-associated antigen 6. Mol Cell Biol 2002; 22: 6298-305.

93 Turner RM, Musse MP, Herr JC, Gerton GL, Moss SB et al. Molecular genetic analysis of two human sperm fibrous sheath proteins, AKAP4 and AKAP3, in men with dysplasia of the fibrous sheath. J Androl 2001; 22: 302-15.

94 Baccetti B, Collodel G, Estenoz M, Manca D, Moretti E et al. Gene deletions in an infertile man with sperm fibrous sheath dysplasia. Hum Reprod 2005; 20 : 2790-4

95 Liu J, Nagy ZP, Joris H, Tournaye H, Smitz J et al. Analysis of 76 total fertilization failure cycles out of 2732 intracytoplasmic sperm injection cycles. Hum Reprod 1995; 10: 2630-6. 
96 Nagy ZP, Liu J, Joris H, Verheyen G, Tournaye $\mathrm{H}$ et al. The result of intracytoplasmic sperm injection is not related to any of the three basic sperm parameters. Hum Reprod 1995; 10: 1123-9.

97 Hazout A, Dumont-Hassan M, Junca AM, Cohen Bacrie P, Tesarik J. Highmagnification ICSI overcomes paternal effect resistant to conventional ICSI. Reprod Biomed Online 2006; 12: 19-25.

98 Berkovitz A, Eltes F, Lederman H, Peer S, Ellenbogen A et al. How to improve IVF-ICSI outcome by sperm selection. Reprod Biomed Online 2006; 12: 634-8.

99 Antinori M, Licata E, Dani G, Cerusico F, Versaci C et al. Intracytoplasmic morphologically selected sperm injection: a prospective randomized trial. Reprod Biomed Online 2008; 16: 835-41.

100 Wilding M, Coppola G, di Matteo L, Palagiano A, Fusco E et al. Intracytoplasmic injection of morphologically selected spermatozoa (IMSI) improves outcome after assisted reproduction by deselecting physiologically poor quality spermatozoa. J Assist Reprod Genet 2011; 28: 253-62.

101 Balaban B, Yakin K, Alatas C, Oktem O, Isiklar A et al. Clinical outcome of intracytoplasmic injection of spermatozoa morphologically selected under high magnification: a prospective randomized study. Reprod Biomed Online 2011; 22 472-6.

102 Oliveira JB, Cavagna M, Petersen CG, Mauri AL, Massaro FC et al. Pregnancy outcomes in women with repeated implantation failures after intracytoplasmic morphologically selected sperm injection (IMSI). Reprod Biol Endocrinol 2011; 9: 99.

103 Dirican EK, Isik A, Vicdan K, Sozen E, Suludere Z. Clinical pregnancies and livebirths achieved by intracytoplasmic injection of round headed acrosomeless spermatozoa with and without oocyte activation in familial globozoospermia: case report. Asian J Androl 2008; 10: 332-6.

104 Tejera A, Mollá M, Muriel L, Remohí J, Pellicer A et al. Successful pregnancy and childbirth after intracytoplasmic sperm injection with calcium ionophore oocyte activation in a globozoospermic patient. Fertil Steril 2008; 90: 1202.e1-5.

105 Kyono K, Nakajo Y, Nishinaka C, Hattori H, Kyoya T et al. A birth from the transfer of a single vitrified-warmed blastocyst using intracytoplasmic sperm injection with calcium ionophore oocyte activation in a globozoospermic patient. Fertil Steril 2009; 91: 931.e7-11.

106 Banker MR, Patel PM, Joshi BV, Shah PB, Goyal R. Successful pregnancies and a live birth after intracytoplasmic sperm injection in globozoospermia. J Hum Reprod Sci 2009; 2: 81-2.

107 Egashira A, Murakami M, Haigo K, Horiuchi T, Kuramoto T. A successful pregnancy and live birth after intracytoplasmic sperm injection with globozoospermic sperm and electrical oocyte activation. Fertil Steril 2009; 92: 2037.e5-9.

108 Taylor SL, Yoon SY, Morshedi MS, Lacey DR, Jellerette T et al. Complete globozoospermia associated with $\mathrm{PLC} \zeta$ deficiency treated with calcium ionophore and ICSI results in pregnancy. Reprod Biomed Online 2010; 20: 559-64.

109 Sermondade N, Hafhouf E, Dupont C, Bechoua S, Palacios C et al. Successful childbirth after intracytoplasmic morphologically selected sperm injection without assisted oocyte activation in a patient with globozoospermia. Hum Reprod 2011; 26: 2944-9.

110 Bongso TA, Sathananthan AH, Wong PC, Ratnam SS, Ng SC et al. Human fertilization by micro-injection of immotile spermatozoa. Hum Reprod 1989; 4: 175-9.

111 Cayan S, Conaghan J, Schriock ED, Ryan IP, Black LD et al. Birth after intracytoplasmic sperm injection with use of testicular sperm from men with Kartagener/immotile cilia syndrome. Fertil Steril 2001; 76: 612-4.

112 Gallo A, Ripoli C, Chemes HE, Coco R. Posibilidad de fertilidad en el Sindrome de Kartagener con microfertilización asistida (Fertility by ICSI in Kartagener's Syndrome). Proc Annu Meet Argent Soc Androl 1999; 8: 34-5.

113 Kamal A, Rhodes CA, Fahmy I, Mansour RT, Aboulghar MA et al. Intyracytoplasmic sperm injection in men with totally immotile ejaculated sperm. Middle East Fertil Soc J 1999; 4: 154-61.

114 Papadimas J, Tarlatzis BC, Bili H, Sotiriadis T, Koliakou K et al. Therapeutic approach of immotile cilia syndrome by intracytoplasmic sperm injection: a case report. Fertil Steril 1997; 673: 562-5.

115 von Zumbusch A, Fiedler K, Mayerhofer A, Jessberger B, Ring J et al. Birth of healthy children after intracytoplasmic sperm injection in two couples with male Kartagener's syndrome. Fertil Steril 1998; 70: 643-6.

116 Brugo Olmedo S, Nodar F, Chillik C, Chemes H. Successful ICSI with sperm from a patient with dysplasia of the fibrous sheath and chronic respiratory disease. Hum Reprod 12: 1497-9.

117 Brugo Olmedo S, Rawe VY, Nodar FN, Galaverna GD, Acosta AA et al. Pregnancies established through intracytoplasmic sperm injection (ICSI) using spermatozoa with dysplasia of fibrous sheath. Asian J Androl 2000; 2: 125-30.

118 Favero R, Rizzo F, Baccetti B, Piomboni P. Embryo development, pregnancy and twin delivery after microinjection of "stump" spermatozoa. Andrologia 1999; 31: 335-8.

119 Stalf T, Sanchez R, Kohn FM, Schalles U, Kleinstein J et al. Pregnancy and birth after intracytoplasmic sperm injection with spermatozoa from a patient with tail stump syndrome. Hum Reprod 1995; 10: 2112-4.

120 Sallam HN, Farrag A, Agameya AF, El-Garem Y, Ezzeldin F. The use of the modified hypo-osmotic swelling test for the selection of immotile testicular spermatozoa in patients treated with ICSI: a randomized controlled study. Hum Reprod 2005; 20 3435-40.

121 Gerber PA, Kruse R, Hirchenhain J, Krüssel JS, Neumann NJ. Pregnancy after laserassisted selection of viable spermatozoa before intracytoplasmatic sperm injection in a couple with male primary cilia dyskinesia. Fertil Steril 2008; 89: 1826.e9-12.

122 Kordus RJ, Price RL, Davis JM, Whitman-Elia GF. Successful twin birth following blastocyst culture of embryos derived from the immotile ejaculated spermatozoa from a patient with primary ciliary dyskinesia: a case report. J Assist Reprod Genet 2008; 25: 437-43.

123 Mangoli V, Mangoli R, Dandekar S, Suri K, Desai S. Selection of viable spermatozoa from testicular biopsies: a comparative study between pentoxifylline and hypoosmotic swelling test. Fertil Steril 2011; 95: 631-4. 